\title{
Recovering A Lost Past: African American Historical Writing in the Nineteenth Century
}

\author{
Stephen G. Hall, Case Western Reserve University
}

Setting Down the Sacred Past: African American Race Histories. By Laurie Maffly-Kipp. Cambridge: Harvard University Press, 2009. 341 pp. \$29.95. hardcover.

Writing on the work of black historians is an important but neglected area of African American historiography. While scholarly writing on black collectors, bibliophiles and historians experienced an uptick in the mid-1980's up through the mid-1990's, it has since taken a backseat to other areas of African American history. ${ }^{1}$ This is especially true when one looks at the outpouring of scholarship on the civil rights and black power movements. Although the study of contemporary African American life (here I am referring to the period from 1954 up to the present) dominates much of the current scholarly production in African American history and studies today, it too provides important lessons about how to study different aspects of the black past. At its inception, the scholarship of civil rights and black power focused on personalities, organizations, and events that informed the civil rights movement: Martin Luther King Jr. or Malcolm X, the Southern Christian Leadership Conference or the Student Non-Violent Coordinating Committee, the Montgomery Bus Boycott or the March on Washington. As time progressed however, historians began to take a longer view of black resistance to Jim Crow. By doing so they enriched our understanding of the dynamics of black struggle against an oppressive state and provided a paradigm for understanding the evolution of black life in contemporary America. ${ }^{2}$

Every historiography then has its own founding stories. If the founding narratives of civil rights and black power rest on certain personalities, organizations and events, we can see a similar reality for African American historiography. One of the most enduring of these founding stories is the idea that the field is largely a product of professionalization in the twentieth century and its major progenitors are W.E.B. DuBois and Carter G. Woodson. While scholars have focused on personalities and the twentieth century as the moment for black history, they have largely overlooked a dynamic era of black historical writing in the nineteenth century. Rather than pre-professional, unsophisticated, or simplistically Afrocentric constructs, black historical production in this period is rich, dynamic and has much to tell us about the subsequent evolution of the field in our contemporary moment. Recovering this lost history is an essential part of what the new scholarship emphasizes. ${ }^{3}$

Laurie Maffly-Kipp's Setting Down the Sacred Past is an important addition to the burgeoning literature on African American historiography. Her 
work builds upon and complements the work of John Ernest, Stephen G. Hall, Julie Des Jardins, and Pero Dagbovie. The work of the aforementioned authors has been a decade in the making and points to the increased interest among scholars and laypersons alike in the nineteenth century and its intellectual variety and complexity. Ernest's Liberation Historiography provides one of the most important interventions in establishing the centrality of nineteenth century historical writing in framing black identity and history. This study's imprint is deeply inscribed on Maffly-Kipp's work. A skillful narrative and theoretical intervention, Liberation Historiography makes a pointed case for the importance of African American historical writing as both a textual and theoretical intervention into the practices and interpretation of history in Nineteenth Century America.

Responding to the trauma of the slave trade and the disruption of history, black writers were, as Ernest suggests, forced to write metahistorically, outside, and beyond established historical traditions to reconstruct a ruptured historical narrative. Ernest not only looks at historical production, but rereads slave narratives and other literary productions by African Americans in the period. Like Maffly-

Kipp, Ernest focuses on the work of men and women in his study. 4

Hall's A Faithful Account of the Race builds on Ernest by expanding the narrative into the early twentieth century and, focuses on historians. In doing so, the book establishes nineteenth century black intellectuals as serious historical writers conversant with the intellectual and ideological constructs of their day. Like Ernest, Hall shows that nineteenth century writing rather than focusing exclusively on vindicationism, proving black worth or contributionism, or demonstrating black contributions to the past, offered deeply humanistic portraits of persons of African descent. These narratives offered rich and compelling portraits of black participation in human and world history from the "first ages of the world." Indeed nineteenth century writers such as Jacob Oson, Maria Stewart, Ann Plato, James W.C. Pennington, Robert Benjamin Lewis, James Theodore Holly, William Wells Brown, William Still, Pauline Hopkins, and Anna Julia Cooper, all of whom are discussed in this work, sketched the vistas of black history broadly throughout the nineteenth century. 5

Julie Des Jardins' Women and the Historical Enterprise, and Pero Dagbovie's The Early Black History Movement also make important contributions to our understanding of African American historiography. Although focusing on the twentieth century, Jardins's Women and the Historical Enterprise provides an important glimpse in the dynamism of female involvement in historical production in the nineteenth century prior to professionalization. She demonstrates in dramatic fashion how the professionalization of the discipline marginalized the work of women whose presence was well-established throughout the nineteenth century. Women's work and their contributions to writing history are an integral part of this book. Additionally, Dagbovie's Early Black History 
Movement explores the culmination of this process, which is the pioneering historical work of Carter G. Woodson and Lorenzo Greene whose ability to combine community work and 'the scientific study of the Negro,' facilitated the professionalization of black history. Maffly-Kipp's work, then, not only builds on previous work, but by focusing on theological or sacred writing adds an unexplored dimension to the previously mentioned considerations of black historiography. Maffly-Kipp's unique contribution to the literature is her masterful discussion of black religious writing and her ability to sketch out the contributions of these writers against the backdrop of a growing literature in black historiography and a rich, but unexplored canvas of nineteenth century black historical writing. 6

Historical writing by African Americans associated with various Christian denominations is a relatively underexplored aspect of black historiography. Maffly-Kipp's work not only fills a gaping lacuna, but adds an important interpretative framework to analyze the themes, personalities, and seminal writings of this diverse and unique group of writings. Like Ernest and Hall, MafflyKipp explores a wide range of motivations and catalysts for why black writers constructed their religiously based narratives. Some of these motivations were based in oppression and racial concerns. Many of these writers however clearly understood how their work could be deployed to explore denominational battles, expound on black contributions to the near and distant past, explore the black presence in the Bible and discuss the role of gender (both femininity and masculinity) in framing the black past. Maffly-Kipp's assertion that race is not the only concern of African American writers should not be taken to mean that race does not matter. Indeed it does, but it was one of many concerns these writers addressed. Black readings of the African past provide an important illustration of this point. Rather than attempts to create a fanciful or mythical past, black writers, Maffly-Kipp argues, drew upon the literary, ideological, and intellectual constructs of their day to craft their histories. They looked to Masonic lore, the Bible, and the dynamic black public sphere. Writers such as Prince Hall, John Marrant, and Martin Delany deployed the image of Africa in different ways. Hall evoked the African past as a means of situating contemporary black institutional practices in a broader historical context. Marrant evoked the Bible and classicism to paint more complex portraits of the ancient black past. Delany, on the other hand, used his narratives to discuss contemporary implications of the African continent as a site of potential immigration and exploitation. These approaches suggest the diversity rather than limits of these writers' visions of the black past, which is a central point of the study.

Beyond ancient Africa, black religious writers were also deeply concerned with providing histories of their respective denominations for posterity. The variations in black religious practice are no better illustrated than in the 
denominational origin stories promoted by black writers. Maffly-Kipp begins with the African Methodist Episcopal Church (AME), the most prominent of black church denominations. The church's origin narrative is premised on the denial of communion to Richard Allen and Absalom Jones at St George's promptly followed by the exodus of these two men and numerous black congregants. While this narrative achieved prominence as the dominant narrative of the independent church movement, it also helped to obscure and marginalize the narratives of other denominations. For example, Christopher Rush, leader of the African Methodist Episcopal Zion Church (AMEZ), was highly critical of the AME church and its leaders. Rush resented the influence of the AME church and how this influence worked to the detriment of other African American denominations. Rush's resentment of the AME church contrasted sharply with the Baptist narrative. Rather than focusing on the dominance of one group or another, Baptists compared their rise to that of the early church. Initially persecuted and hampered by the poverty and illiteracy of its early leaders, the Baptists, like the early Christian church, eventually gained influence and power. MafflyKipp's strongest point here is the notion of a monolithic black church united around singular principles and narratives did not exist. Rather these denominational histories created cosmopolitan notions of Christian fellowship linking members across time and space.

Maffly-Kipp is just as persuasive in discussing the domestic discourse of black churches as she is their broader international and Diasporic implications. Focusing on Haiti, and to a lesser extent on Liberia, Maffly-Kipp fleshes out the complexity of black engagement with the wider world. Her discussion of African American engagement with Haiti from 1804, the year the nation became the first free black republic in the Western hemisphere, through the end of the nineteenth century complicates black understandings of Haiti's meanings in the period. Like Hall, she shows that African Americans harbored a wide range of feelings about Haiti. Rather than the common assertion that American blacks uncritically celebrated the Haitian revolution's aftermath, she clearly shows this was not the case. Initially plunged into instability and chaos and internecine warfare between the Northern and Southern portions of the island, by the 1820's Haiti achieved a modicum of stability and various leaders encouraged emigration. One of the strongest supporters of this position was Prince Saunders. Saunders, author of the Haytien Papers, played an important role in promoting the country through lecture tours in the United States. Saunders efforts were indirectly assisted by the machinations of the American Colonization Society (ACS) which beginning in 1817 promoted colonization to Liberia as a solution to America's race problems. As Maffly-Kipp shows, black clergy such as Richard Allen and James Forten, a layperson in the Episcopal Church, viewed Haitian emigration as a means of deflating the ACS's "colonizing scheme." Moreover, these clergy even promoted Haiti as a "New world Canaan," a promised land. 
The realities on the ground for new African American settlers proved more complex than challenging colonization or the idea of a modern day promised land. Black settlers found it difficult to reconcile their Protestant beliefs with the dominant practices of Catholicism and the prominence of Voodun in the native religious practices on the island. This story would repeat itself with different outcomes in the 1850's and 1880's. 7

In the 1850's, after numerous coups and instability, Haiti again emerged as a potential site for African American emigration under the leadership of Faustin I., Delany celebrated this possibility in his treatise on emigration, The Condition, Elevation, Emigration and Destiny of the Colored People (1852) and authors such as William Wells Brown and James Theodore Holly likened contemporary struggles by antislavery forces against slavery to those encountered by Haitians in the late eighteenth century. In the 1880's Haiti, now recognized by the United States as a sovereign power, coupled with the emancipation of African Americans ushered in a new set of possibilities. The redemption and uplift of Africa became the new byword for civilization and progress. Black leaders embraced the missionary impulse and offered themselves as models for social and moral advancement.

Liberia maintained its sovereignty in a period dominated by European expansion and imperialism and was one of only three nations that managed to do so (Haiti and Ethiopia being the other two). Liberia's historical trajectory then distinguished it as a source of black possibility. Maffly-Kipp does an excellent job of discussing the perspectives of the African American clergyman Alexander Crummell and his West Indian counterpart Edward Wilmot Blyden. Both men played an important role in attempting to improve the College of Liberia. The fact that these men pursued different paths is also intriguing. Crummell served as a stalwart of Western civilization. On the other hand, Blyden embraced many aspects of the indigenous cultures of Liberia and even viewed Islam as a positive force in promoting literary and academic achievement in Africa.

Although Maffly-Kipp devotes considerable attention to the first half of the nineteenth century, she does not neglect the second half of the century. Indeed, the period from the 1880's up to 1920's witnessed an outpouring of historical works by writers associated with the church. The themes of these works were varied and ran the gamut from appeals for missionary activism, to stressing Christian ethics and morals, to celebrations of the African past (Egypt and Ethiopia), and to assertions regarding the skin colour of Christ. Churches such as the AME and CME (Colored Methodist Episcopalian) and the Black Baptists expanded their printing concerns. These groups published newspapers and journals and used these organs to promote their respective missions. Black writers linked their theological missions to the broader prerogatives of emancipation. Indeed, as Maffly-Kipp shows, the dynamism of this pre-professional produc- 
tion suggests the richness and diversity of black history produced by clergy in the nineteenth century that has been largely overlooked and homogenized in the twentieth century, a point similarly made by Des Jardins in her study Women and the Historical Enterprise. It clearly stands as a precursor and foreshadows the rise of professionalized historical practices discussed in Dagbovie's work. ${ }^{8}$

Maffly-Kipp's discussion of the involvement of black women as religious writers and historians ranks as one of the most important discussions in the book. Although the discussion of gender is incorporated throughout, her chapter length examination of women at the end of the book is also very useful. She highlights the work of well-known writers such as Maria Stewart, Frances Ellen Harper, Pauline Hopkins, and Anna Julia Cooper as well as those lesser known such as Lelia Amos Pendleton, Gertrude Mossell, and Priscilla Dunjee Houston. Maffly-Kipp notes that although women did not deploy direct action and protest as the dominant modes of historical expression, their use of sentiment and veiled messages nonetheless offered powerful examples of historical engagement with domestic and international issues confronted by African Americans throughout the nineteenth century. ${ }^{9}$

In conclusion, Maffly-Kipp's Setting Down the Sacred Past is an important contribution to the literature on African American historiography. Clearly building on the work of Ernest, Hall, Des Jardins, and Dagbovie, she charts new ground in expanding our understanding of nineteenth century historiography. By highlighting the diversity of black writing, subject matter, ideology, and modes of dissemination, Maffly-Kipp expands our understanding of this historical genre. She compliments the current historiography and charts new directions. Through an examination of black religious writing in the nineteenth century, she has added a new and dynamic element to considerations of black intellectual thought in the nineteenth century. In doing so she has provided a guidebook for the complex and nuanced terrain of black religious writing in the era before professionalization.

\section{NOTES}

1 A few of the more important studies include August Meier and Elliott Rudwick, Black History and the Historical Profession, 1915-1980 (Urbana: University of Illinois Press, 1986); Darlene Clark Hine, ed., The State of African American History: Past, Present and Future (Baton Rouge: Louisiana State University Press, 1986); Benjamin Quarles, Black Mosaic: Essays in Afro-American History and Historiography (Amherst: University of Massachusetts Press, 1988); Elinor Des Verney Sinnette, W. Paul Coates and Thomas C. Battle, Black Bibliophiles and Collectors: Preservers of Black History (Washington, D.C.: Howard University Press, 1990); Jacqueline Goggin, Carter G. Woodson: A Life in Black History (Baton Rouge: Louisiana State University Press, 1993); Kenneth Robert Janken, Rayford Logan and the Dilemma of the African-American Intellectual (Amherst: University of Massachusetts Press, 1993) and Elizabeth Raul Bethel, The Roots of African American Identity: Memory and History in Antebellum Free Communities (New 
York: St Martin's Press, 1997).

2 Here I am only citing the classic works on the civil rights movement that were instrumental in constructing the initial paradigms on how scholars frame and discuss the movement. See Juan Williams, Eyes on the Prize, America's Civil Rights Years, $1954-1965$ (New York: Penguin Books, 1988); Aldon Morris, Origins of the Civil Movement: Black Communities Organizing for Change (New York: Free Press, 1988); Taylor Branch, Parting the Waters: America in the King Years, 1954-1963 (New York: Simon Schuster, 1989) and Clayborne Carson, In Struggle: SNCC and the Black. Awakening of the 1960's (Cambridge: Harvard University Press, 1995).

3 For the founding narratives of African American historiography see August Meier and Elliott Rudwick, Black History and the Historical Profession, 1915-1980 (Urbana: University of Illinois Press, 1986), 1-73 and John Hope Franklin, "On the Evolution of Scholarship in Afro-American History," in Darlene Clark Hine, ed., The State of African American History: Past, Present and Future (Baton Rouge: Louisiana State University Press, 1986), 13-24.

4 See John Ernest, Liberation Historiography: African American Writers and the Challenge of History, 17941861 (Chapel Hill: University of North Carolina Press, 2004), 1-39 and 95-219.

5 See Stephen G. Hall, A Faithful Account of the Race: African American Historical Writing in Nineteenth Century America (Chapel Hill: University of North Carolina Press, 2009), 1-85.

${ }^{6}$ Julie Des Jardins titles the first chapter of her study Women and the Historical Enterprise in America, "From Feminine Refinement to Masculine Pursuit, 1880-1920." In this chapter, she sketches out the diverse roles that women played in historical writing and production prior to the professionalization of history. See Julie Des Jardins, Women and the Historical Enterprise: Gender, Race and the Politics of Memory, 1880-1945 (Chapel Hill: University of North Carolina Press, 2003), 13-52. See Pero Dagbovie, The Early Black History Movement, Carter G. Woodson and Lorenzo Johnston Greene (Urbana: University of Illinois Press, 2007), 1-15.

7 See Hall, A Faithful Account of the Race, 86-123.

8 See Des Jardins, Women and the Historical Enterprise, 1-13 and Dagbovie, The Early Black History Movement, 44-62.

${ }^{9}$ Here too Maffly-Kipp builds on the work of Ernest who discusses the historical inferences in the work of Maria Stewart, Jarena Lee, Zilpha Elaw, and Harriet Jacobs, Liberation Historiography, 63-64 and 193-202 and Hall who explores the historical work of Maria Stewart, Ann Plato, Anna Julia Cooper, Pauline Hopkins, Gertrude N.F. Mossell, and Leila Pendleton. See A Faithful Account of the Race, 44-47, 78-79, and 174-187.

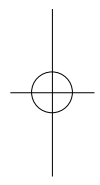

